RESIDENT

\& FELLOW

SECTION

Section Editor

Mitchell S.V. Elkind,

MD, MS

Dimitri Renard, MD

Laurent Collombier, MD

Giovanni Castelnovo, MD

Pierre Labauge, MD, $\mathrm{PhD}$

Address correspondence and reprint requests to Dr. Dimitri Renard, Department of Neurology, CHU Nîmes, Hôpital Caremeau, Place du Pr Debré, 30029 Nîmes Cedex 4, France dimitrirenard@hotmail.com

\title{
Teaching NeuroImages: \\ FDG-PET in progressive supranuclear palsy
}

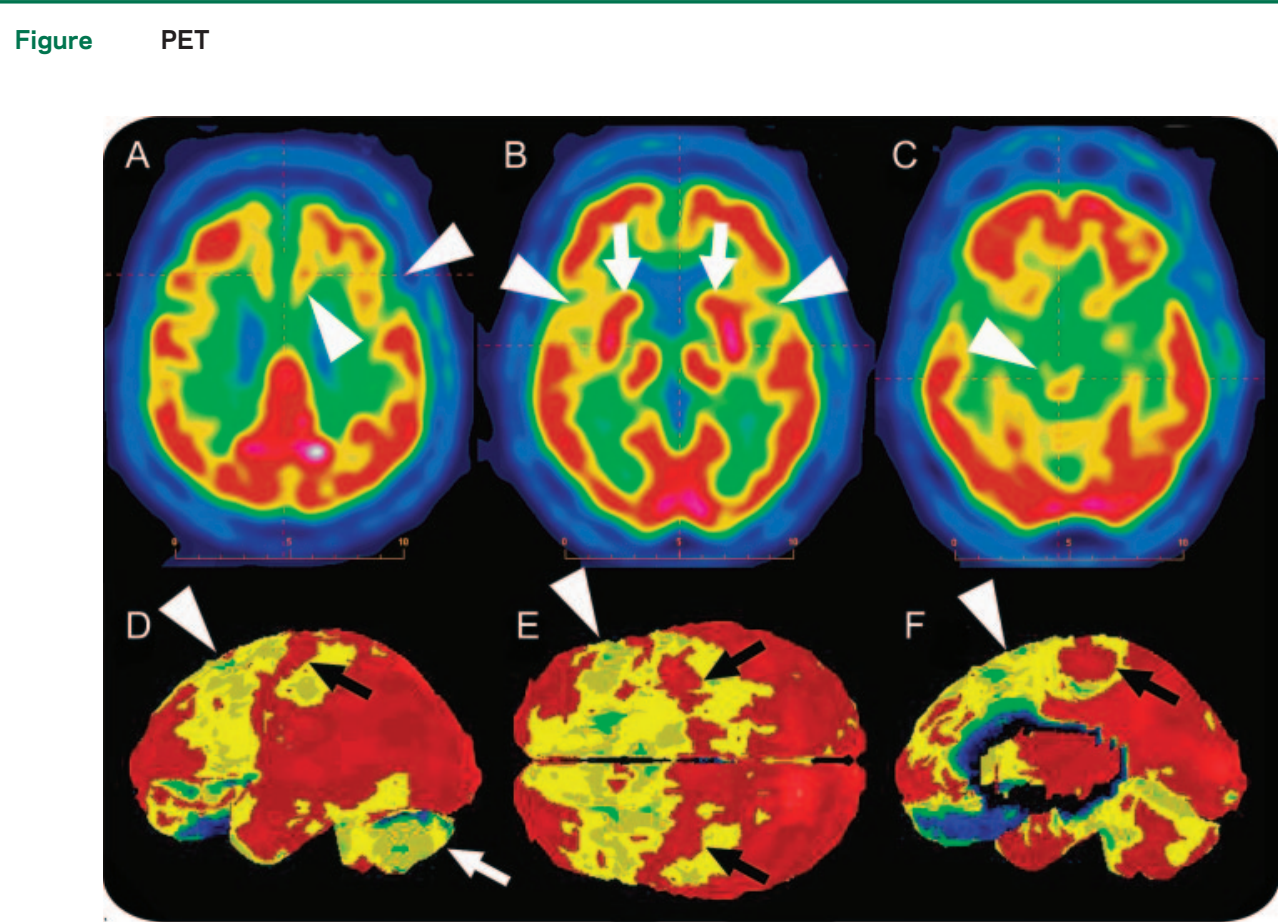

Axial FDG-PET images show marked bilateral hypometabolism in frontal cortex (A, arrowheads), especially paramedian, insular cortex ( $B$, arrowheads), the head of the caudate nucleus ( $B$, arrows), and the brainstem ( $C$, arrowheads). Threedimensional FDG-PET reconstruction images (D, lateral view; $F$, superior view; $E$, medial view) confirm hypometabolism in the lateral and paramedian frontal cortex (arrowheads) respecting the primary motor area (black arrows), and show decreased metabolism in the cerebellum as well (white arrow).

A 74-year-old man presented with falls, dysphagia, and personality change.

Examination showed axial parkinsonism (without response to levodopa), low pitched dysarthria, supranuclear vertical gaze palsy, decreased blinking, square-wave jerks, primitive reflexes, apathy, and decreased verbal fluency. Brain MRI showed dorsal midbrain and frontal paramedian atrophy. Probable progressive supranuclear palsy (PSP) was diagnosed.

${ }^{18}$ Fluorodeoxyglucose (FDG)-PET showed bilateral hypometabolism in the lateral and midline frontal cortex, insular cortex, head of caudate nucleus, brainstem, and cerebellum (figure), consistent with described FDG-PET findings in PSP. ${ }^{1,2}$ Although not required for diagnosis of probable PSP, FDG-PET may help differentiate parkinsonian syndromes. In Parkinson disease, FDG-PET most frequently shows hypermetabolism of the dorsolateral putamen. Cerebellar hypometabolism has been reported in patients with PSP but is not specific. Predominant cerebellar together with bilateral putamen hypometabolism favors multiple system atrophy. ${ }^{2}$

\section{REFERENCES}

1. Juh R, Kim J, Moon D, Choe B, Suh T. Different metabolic patterns analysis of parkinsonism on the $18 \mathrm{~F}-\mathrm{FDG}$ PET. Eur J Radiol 2004;51:223-233.

2. Eckert T, Barnes A, Dhawan V, et al. FDG PET in the differential diagnosis of parkinsonian disorders. Neuroimage 2005;26:912-921. 


\section{Neurology}

\section{Teaching NeuroImages: FDG-PET in progressive supranuclear palsy \\ Dimitri Renard, Laurent Collombier, Giovanni Castelnovo, et al. \\ Neurology 2010;74;e60 \\ DOI 10.1212/WNL.0b013e3181d7d871}

\section{This information is current as of April 5, 2010}

\section{Updated Information \& Services}

References

Subspecialty Collections

Permissions \& Licensing

Reprints including high resolution figures, can be found at: http://n.neurology.org/content/74/14/e60.full

This article cites 2 articles, 0 of which you can access for free at: http://n.neurology.org/content/74/14/e60.full\#ref-list-1

This article, along with others on similar topics, appears in the following collection(s):

All Neuro-ophthalmology

http://n.neurology.org/cgi/collection/all_neuroophthalmology

MRI

http://n.neurology.org/cgi/collection/mri

PET

http://n.neurology.org/cgi/collection/pet

Progressive supranuclear palsy

http://n.neurology.org/cgi/collection/progressive_supranuclear_palsy

Information about reproducing this article in parts (figures,tables) or in its entirety can be found online at:

http://www.neurology.org/about/about_the_journal\#permissions

Information about ordering reprints can be found online:

http://n.neurology.org/subscribers/advertise

Neurology ${ }^{\circledR}$ is the official journal of the American Academy of Neurology. Published continuously since 1951, it is now a weekly with 48 issues per year. Copyright . All rights reserved. Print ISSN: 0028-3878. Online ISSN: 1526-632X.

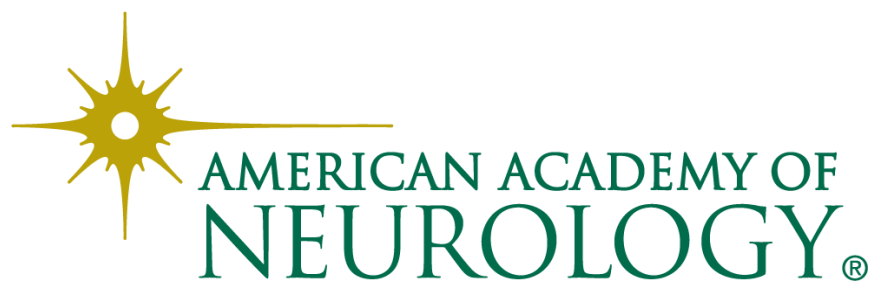

